\title{
The Influence of Democratic Parenting Patterns To The Creativity of Early Ages
}

\author{
Desta Alicha Istisaroh' \\ ${ }^{1}$ Early Childhood Education \\ Muhammadiyah Surakarta university \\ Dr. Choiriyah Widyasari, M.Psi² \\ ${ }^{1}$ Early Childhood Education \\ Muhammadiyah Surakarta university
}

\section{ABSTRACT}

Aim: This study aims to determine the relationship of parenting parents with group B children's creativity in the Klaten Pedan region. Method: This research is a quantitative study with a correlational approach. The study population was parents of children aged 5-6 years in the Klaten Pedan region. The sampling technique used was random sampling with the number of respondents 30 parents. The data collection method uses a questionnaire or questionnaire. The data analysis technique used is the Pearson correlation test with SPSS tools. Results and discussion: Based on the results that there is a significant relationship between creativity and parenting as indicated with the significance of $0,000<0.05$ with a correlation magnitude of 0.690 . External factors affecting creativity in addition to parenting patterns, namely factors from the school environment and surrounding community environment Therefore the sig value of $0.123>$ 0.05.Conclusion: there is a linear relationship between parenting parents and children's creativity.

\section{Keywords:}

parenting parents, early childhood creativity

\section{CORRESPONDING AUTHOR:}

email: destaalicha013@gmail.com

Manuscript submitted October 10, 2020; accepted December 27, 2020.

Copyright: (02019 This is an open access article under the terms of the Creative Commons Attribution License, which permits unrestricted use, distribution, and reproduction in any medium, provided the original author and source are credited.
ECRJ (Early Chilhood Research Journal)

ISSN Numbers: Print, 2655-6448; Online, 2655-9315

ADDRESS

Website: http://journals.ums.ac.id/index.php/ecrj Address: Pendidikan Guru PAUD Universitas Muhammadiyah Surakarta

A. Yani Street No. 1, Pabelan, Kartasura, Surakarta, Indonesia Telp. +62-271-717417 ext.

Email: ecrj@ums.ac.id 
http://journals.ums.ac.id/index.php/ecrj

\section{INTRODUCTION}

According to Husna et al (2019)Education is needed by every human being to grow and develop the capabilities they have. Therefore, education is an inseparable factor. Implementation of early childhood guidance carried out in a kindergarten educational institutionrealize a formation from learning education. Education childhood very influential to child growth and development into the future. Schools for young children on formal channels that provide education for preschoolers intends as a service needs of children to improve children's development equally.

Bacharuddin Mustafa (2002: 35) in Susanto (2017), early childhood is a child who is aged between 1-5 years. This understanding is based on the limits of psychological development which includes infants or infants aged 0-1 years, early childhood aged 1-5 years, late childhood (late childhood) aged 6-12 years.

According toLestari (2019)some children spend time with family, so the task of the family in shaping the child's personality is very important. As parents as educators and caregivers of children are asked to be able to be careful of the various behaviors and emotions of children.

Utami Munandar in Susanto (2017), states that the conclusions from various previous studies, the actions of parents to enhance the development of their children's creativity by assessing children's ideas and opinions, giving children freedom to be reasonable and imagining, giving children freedom to make their own decisions, supporting children in order to know new things, provide support for activities carried out by children, give praise to children, encourage children to be independent, and good communication with children.
The Influence of Democratic ...

According toPuspita et al (2018)parenting style of children is very influential on themselves and their behavior. Parenting parenting functions to train children to apply the rules given by parents. Where are early childhood in the golden period. The role of parents is very important for children's growth and development. Therefore, parents still prioritize the interests of their children so that the child's development for the better.

There are three types of parenting parents, namely (a) democratic parenting, a parenting style that is marked by parents' encouragement of children to foster independent, responsible and respect other people, approaches to children are gentle. (b) formparenting authoritarian, constitute how to educate ones be marked through behaving parentsfirm and strict with children, parents almost never give praise to children, communication with children tends to be one-way. (c) whereas permissive parenting, is parenting which has the character of parents less applying punishment when the child is guilty, childgiven permission to be independent, parents have a high acceptance but under supervision is less than the maximum and given permission to make their own decisions and be able to do something they want.

The nature of democratic parenting is that children are considered like themselves to parents and involve children when making decisions, prioritizing their children's needs, but do not hesitate in controlling, and support the freedom given to children in order to sort out and carry out an activity or activities, communication in children is gentle.

Munandar (2004: 35) in Susanto (2017) efforts to help children realize creativity 
http://journals.ums.ac.id/index.php/ecrj

according to Munandar (2004: 35) children need training in certain skills according to their interests. As an educator or parent is tasked with creating ideas that stimulate children's thinking patterns and creative skills, by preparing tools and infrastructure that support the development of children's creativity.

Susanto (2017) Creativity as an ability that exists in children to be developed early. Each child has creative abilities that can be optimally developed early on. Therefore, children need educational encouragement to increase their creativity. Each child has different creative abilities. The experts classify the characteristics of creative individuals, such as: having curiosity, motivated by a challenge, confident in making decisions, never giving up, respecting nature, having a high sense of humor, curiosity of unknown knowledge, imaginative. However important factors that influence the development of creativity are parenting parents, teachers, and the environment.

Rahmalina (2017)childhood is the peak period with creativity that needs to be maintained and developed as well as creating an environment with her creativity. The level of creativity of children is based on characteristics and delusions arise from children's hallucinations. Children have freedom and freedom of activity so that children's creativity is essentially a mindset that is driven as a human mindset.

Susanto (2017) states that to improve children's creativity, teachers and parents need to stimulate children to observe and ask about new things around them. Teachers and parents need to provide infrastructure to support children's creativity. Like, providing story books, pictures that attract the attention of children and so on. Teachers
The Influence of Democratic ... and parents should not forbid children to express their opinions so that children have confidence.

So, children's creativity is the development of children's behavior to express themselves freely, children can imagine and explore what they do. To increase children's creativity is supported by parenting applied by parents.

According to Hurlock inReswita (2017) argues that "the actions of parents on their children is very influential on the nature and behavior of children, good viewing behavior, respect for other people's behavior and affect the quality of the relationship between parents and their children.

According to Puspita et al (2018)children who have the characteristic of high creativity that are always curious, have a lot of interest, have a fondness, like creative activities tend to be challenging, not afraid in making decisions and not afraid to admit their mistakes by boldly expressing their opinions. Creative children are children who have a high imagination and always have ideas to do something. So parents and teachers as educators must provide infrastructure and provide sufficient attention and affection to develop their children's creativity.

Factors inhibiting children's creativity according to Utami Munandar in Susanto (2017) are not giving freedom to children to express their opinions, parents do not supervise children, parents do not pay attention to children's needs, parents are impatient with children, parents forbid noisy children, parents do not allow children playing with neighbors, and parents being restrained children.

Kholifah (2018)family environment becomes the initial environment for children. Therefore, as a family must be 
http://journals.ums.ac.id/index.php/ecrj

aware of the importance of it. Parents play an important role in determining choices for children through the direction and guidance of parents will be able to trigger the child's future growth and development. Factors that influence the growth and development of children's behavior, one of which is the pattern of parenting which is the nature and behavior of parents in caring for their children.

From this description, it can be concluded that children's creativity will develop if parents and teachers always act democratically. Through attitudes that capture and respect the ideas and ideas of children, and support children to dare to express their ideas and ideas.

Based on the above problems the researcher wants to take the title "Effect of Parenting Democratic To Creativity Early childhood"which is in the Pedan Klaten region. This research was conducted to examine how much influence the parenting democratic parenting has on children's creativity.

\section{METHOD}

This research is a quantitative study using a correlational approach, which is to explore the relationship between independent variables on the dependent variable. According to Sugiyono (2016, p.13) quantitative approach is based on the philosophy of positivism which analyzes numerical data that is processed by statistical methods that aim to test the
The Influence of Democratic .... hypotheses that have been set. Correlation method is a way to measure two types of variables, namely parenting and children's creativity. The purpose of using the correlation method is to find out the significance of a variable with other variables (Asep \& Baharudin, 2014, p. 7).

This research was conducted in the Pedan region, Klaten. The population of this research are children and parents of children aged 5-6 years from the Klaten Pedan area. The sampling technique used is random sampling. The sample used in this study is children aged 5-6 years in Kauman village as many as 30 children and 30 parents.

Data collection methods used namelyquestionnaire (questionnaire). Questionnaire is an indirect data collection technique that contains several questions or written statements answered by respondents (Sugiyono, 2013, p.199). Researchers used a questionnaireas quantitative data collection about parenting patterns applied by parents to the development of their children's creativity. The questionnaire will be arranged and developed in the form of a grid based on the operational definitions that have been developed. The total statement consists of 50 statements presented in the form of a questionnaire with a Likert scale. The questionnaire has five answer options. The answer options consist of Very Often (SS), Frequently (S), Sometimes (KK), Never (TP), and Very Never (STP). Five answer options with each value are: 
Table 1.1 Size of the Answer Questionnaire Options

\begin{tabular}{|c|c|}
\hline $\begin{array}{l}\text { Option } \\
\text { The answer }\end{array}$ & $\begin{array}{l}\mathrm{S} \\
\mathrm{c} \\
\mathrm{o} \\
\mathrm{r} \\
\mathrm{e}\end{array}$ \\
\hline $\begin{array}{l}\text { Very } \\
\text { Often }\end{array}$ & 5 \\
\hline Often & 4 \\
\hline $\begin{array}{l}\text { Sometimes- } \\
\text { Sometimes }\end{array}$ & 3 \\
\hline $\begin{array}{l}\text { Not } \\
\text { Ever }\end{array}$ & 2 \\
\hline $\begin{array}{l}\text { Very not } \\
\text { Ever }\end{array}$ & 1 \\
\hline
\end{tabular}

Table 1.2 Indicators of parenting parenting and children's creativity

\begin{tabular}{|c|c|c|c|}
\hline Variable & Aspect & Indicator & Item problem \\
\hline $\begin{array}{l}\text { Parenting } \\
\text { Parents }\end{array}$ & Democratic & $\begin{array}{l}\text { 1. } \begin{array}{l}\text { Children are } \\
\text { involved in making } \\
\text { decisions }\end{array} \\
\text { 2. Control over } \\
\text { children is loose } \\
\text { 3. Give freedom to } \\
\text { children } \\
\text { 4. The approach to } \\
\text { children is warm }\end{array}$ & $\begin{array}{l}1,2 \\
3,4 \\
5,6 \\
7,8,9\end{array}$ \\
\hline & Authoritarian & $\begin{array}{l}\text { 1. Children must obey } \\
\text { and obey according } \\
\text { to the wishes of } \\
\text { parents } \\
\text { 2. Parental } \\
\text { supervision of the } \\
\text { child's behavior is } \\
\text { really thorough } \\
\text { 3. Parents barely had } \\
\text { time to say a token } \\
\text { of appreciation } \\
\text { Contact with } \\
\text { children is always } \\
\text { instructed or } \\
\text { instructed }\end{array}$ & $\begin{array}{c}10,11 \\
12,13,14 \\
15 \\
16,17,18,19\end{array}$ \\
\hline & Permissive & $\begin{array}{l}\text { 1. parents have a high } \\
\text { acceptance but } \\
\text { under supervision is } \\
\text { not optimal and } \\
\text { given permission to } \\
\text { make their own } \\
\text { decisions and be }\end{array}$ & $\begin{array}{l}20,21 \\
22,23\end{array}$ \\
\hline
\end{tabular}


http://journals.ums.ac.id/index.php/ecrj

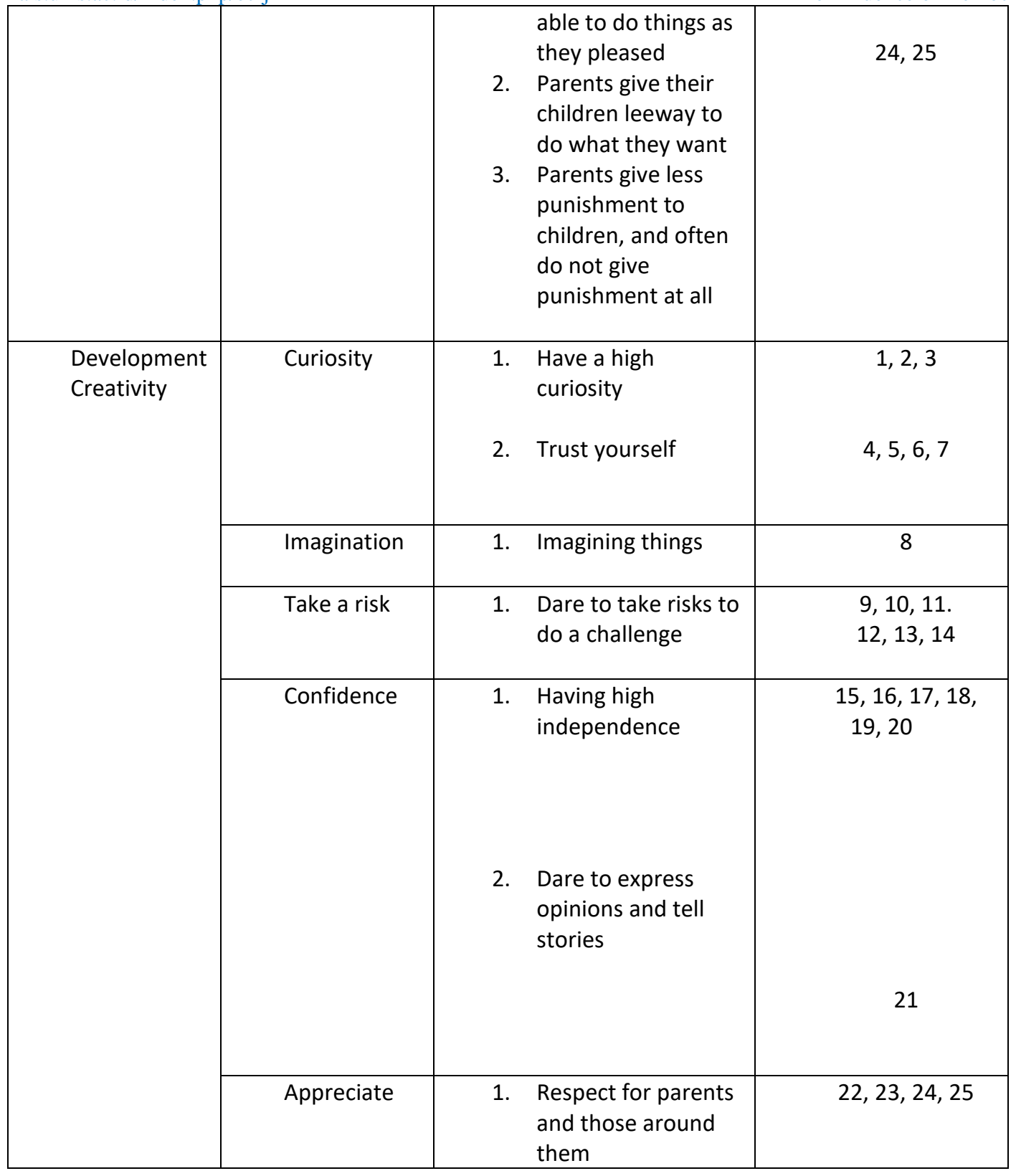


Test classic assumptions with the data requirements must be normal and linear. Normality test using the Shapiro Whik Test and Linearity Tests, the data obtained are normally distributed and linearly patterned, so the correlation analysis can be continued. This study uses the Shapiro Whik Test because the number of respondents is relatively small (less than 60).

Data analysis techniques used in research using Pearson correlation. Sugiyono (2013) states that the Pearson correlation test is used to look for relationships and states that the hypothesis of the relationship of two variables (bivariate) in the form of intervals or ratios, and the data sources of two or more variables are the same.

Retrieval of data using the observation sheet (checklist) and then analyzed with SPSS (Statistical Package for Social Sciences) aids from these aids can be seen a significant relationship between the two variables.

In addition to seeing the influence of parenting with children's creativity, it is important to know the categorization of children's creativity and parenting applied by each parent through descriptive analysis. Children's creativity is categorized into two, high and low. Children are said to have a high level of creativity if they score more than average. Children who have low creativity if the scores obtained are below average. Determination of parenting can be seen from the highest number of scores of each parenting then conclusions drawn. The maximum score that can be obtained for each parenting is 125 , and the minimum score is 25 . This study uses the correlation method. Correlation method can be used to determine the relationship between variables with other variables (Asep \& Bahrudin, 2014, p. 7). The independent variable in this study is parenting, and the dependent variable is creativity.

\section{RESULTS AND DISCUSSION}

Parenting data were obtained by distributing questionnaires to the children's parents as respondents. Questionnaires were given to parents of 30 children. Parenting is categorized into two categories, low and high. Each parenting has a different category. The different categorizations are illustrated in the following diagram:

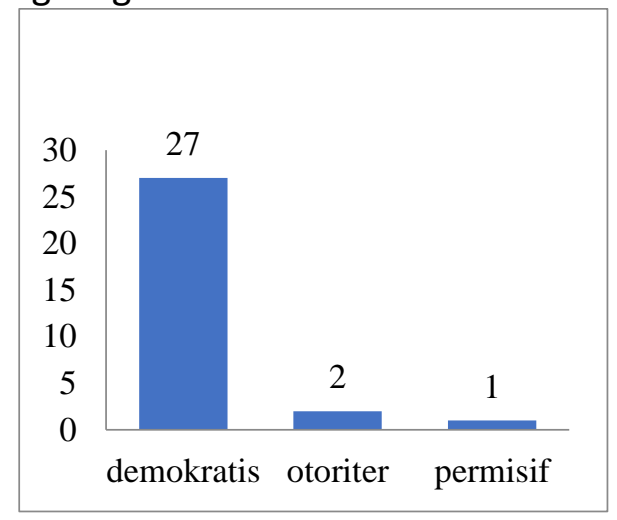

Parenting frequency category diagram

Based on the parenting frequency diagram above it can be said that each parenting category is categorized as low and high. Democratic parenting has the results of 27 parents in the high category obtained a percentage of $89 \%$,while authoritarian parenting there are results 2 parents in the low category obtained a percentage of $6.6 \%$ and permissive parenting there is a result of 1 parent in the low category obtained a percentage of $3.3 \%$.

Data on children's creativity was obtained by distributing questionnaires to parents of children as respondents. Creativity variables are categorized as low creativity and high creativity. The results of the study found that 27 children in the high category obtained a percentage of $89 \%$, while 3 children in the low category gained a percentage of $9.9 \%$. 


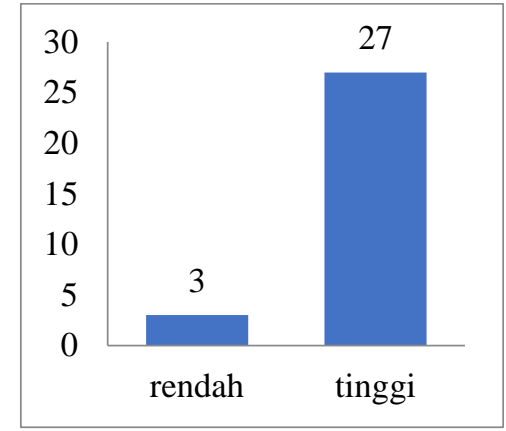

Frequency category diagram of creativity

Before conducting data analysis, the researchers conducted a Validity and Reliability Test on the two variables as follows:

1. Validity test

The validity test in this study uses the Pearson test. Based on the results of the validity test, it shows that the parenting variable consists of 25 statement items which were given to 30 respondents and obtained 21 statement items with a calculated value $(0.450$ to 0.849$)>r$ table $(0.3610)$ so that it can be concluded 21 statement items from the pattern variable foster is declared valid, while 4 items have a calculated value $(0.077$ $0.206)<$ r table $(0.3610)$, so 4 items are declared invalid. Whereas the creativity variable consisted of 25 statement items which were given to 30 respondents and 21 statement items were obtained which had rcount value (0.406-0.813)> $r$ table (0.3610), so that it could be concluded 21 statement items from the creativity variable were declared valid, while 4 The item has a calculated value (0.239$0.257)<$ table (0.3610),

2. Reliability

\begin{tabular}{|c|c|c|c|}
\hline Variabl & $\begin{array}{ll}\text { Cronbac } & \text { h's } \\
& \text { Alpha }\end{array}$ & $\mathrm{N}$ & Ket \\
\hline
\end{tabular}

\begin{tabular}{|c|c|cc|cl|}
\hline \multicolumn{1}{|c|}{$\begin{array}{c}\text { Pattern } \\
\text { Foster } \\
\text { care }\end{array}$} & 0.949 & $1^{2}$ & & $\begin{array}{l}\text { Reliabil } \\
\text { ity }\end{array}$ \\
\hline Creativ & 0.920 & 1 & 2 & $\begin{array}{l}\text { Very } \\
\text { High }\end{array}$ \\
\hline ity & & 1 & & Reliabil \\
ity & $\begin{array}{l}\text { Very } \\
\text { High }\end{array}$ \\
\hline
\end{tabular}

Based on the results of the reliability test knowing each variable has a Cronbach's Alpha value between $0,80-1,000$ so that it can be concluded that reliability is in the high category.

After testing the validity and reliability testing, researchers conducted data analysis to answer the hypothesis of the relationship between parenting and children's creativity is the Pearson correlation. Correlation test is done that is by using the Pearson correlation test because to see the relationship between the independent variables to the dependent variable.

Table 2.1 Normality Test

\begin{tabular}{|c|c|c|}
\hline $\begin{array}{c}\text { Varia } \\
\text { ble }\end{array}$ & Si & Ket \\
\hline $\begin{array}{c}\text { Pare } \\
\text { nting }\end{array}$ & 0. & $\begin{array}{c}\text { Nor } \\
\text { mal }\end{array}$ \\
\hline $\begin{array}{c}\text { Creat } \\
\text { ivity }\end{array}$ & 867 & Nor \\
\end{tabular}

Based on the results of the normality test shows that each variable has a Significant value $>0.05$, so that it shows normal data distribution.

Table 2.2 Linearity Test

\begin{tabular}{|c|c|c|}
\hline $\begin{array}{c}\text { Varia } \\
\text { ble }\end{array}$ & $\mathrm{g}$ & $\mathrm{t}^{\mathrm{Ke}}$ \\
\hline $\begin{array}{c}\text { Paren } \\
\text { ting * } \\
\text { creativity }\end{array}$ & 123 & Lin \\
\hline
\end{tabular}


Based on the results of the linearity test, a sig value of $0.123>0.05$ is obtained, so there is a linear relationship between parenting parents and children's creativity.

Table 2.3 Pearson Test

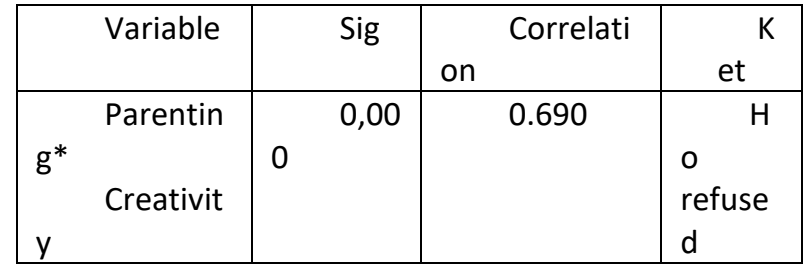

Research hypotheses namely:

Ho: There is no relationship between parenting with children's creativity

$\mathrm{Ha}$ : There is a relationship between parenting and children's creativity

Pearson test results have a significant relationship to parenting as indicated by the significance value of $0,000<0.05$ with a magnitude of correlation of 0.690 .

Based on the data pattern of parenting, that parenting is applied by parents to children in the Pedan area, on average parents apply democratic parenting to increase their children's creativity. Onresearch conducted by researchers, that democratic parenting relatively high, whereas authoritarian parenting and permissive parentingrelatively low.

The results of the analysis of the research data prove that there is a significant relationship to parenting parents with children's creativity. That the value of sig $<r$ table is obtained, with a value of $0,000<0.05$ with a correlation magnitude of 0.690 .

Quoted from articles written by (Sustainable, 2019)states that parents are the main family responsible, from parents all the good and bad are received by their children, parents as a model in all behaviors. Children are cared for in ways that make children feel comfortable, safe, full of spirit, and feel acknowledged for their existence or vice versa.
In research Handayani et al (2017) that families must be able to create and maintain a sense of security and comfort for their children when playing in an effort to increase children's creativity. When children are able to create something new, children will do it again. Creativity fosters feelings of pleasure and satisfaction towards children. Appreciation from parents and family is very influential on the development of children's creativity.

In addition to parents and family, external factors that affect children's creativity are the school environment and the surrounding community and the parenting patterns applied by parents. Parenting patterns include love and affection, and a good relationship between parents and children, the attitude parents show to children, and various rules created by parents to control children's behavior.

This is consistent with the theory put forward by Handayani et al (2017) that creativity is an individual component and social behavior since time immemorial. The growth of creativity can be achieved through the family environment and the school environment. Children need a conducive environment to be able to improve and develop their talents, which include intelligence, creativity, and motivation, as well as their ability to optimally realize their personal needs.

From the results of this study, obtained 27 parents who apply democratic parenting, and 3 parents apply authoritarian parenting and permissive parenting.

This is consistent with the theory Soetjiningsih (1995) in Diana (2019) democratic parenting can provide good stimulation for children.

Madyawati (2016) in Helmawati (2015) said that democratic parenting prioritizes the needs of children, but there are still giving 
directions or controlling children. Parents who use democratic parenting type are realistic about the abilities or skills of children, parents do not expect excessive or who exceed the limits of the ability of children. Parents also give freedom to children to choose, do, and think of an action and warm approach to children.

From the results of the study, that democratic parenting affects the ability of children's creativity. Good parenting patterns are very influential in the development of children's creativity, where children are educated and trained in accordance with the stages of child development known to their parents. Parents give freedom to children, but parents also have full control over what children do.With behavior that listens and respects the opinions of children, in order to encourage children to convey ideas or tell stories about their experiences, so that children do not feel constrained and children feel valued or respected for their existence.

\section{CONCLUSION}

From the results of the research and discussion that conclusion can be drawn the influence of parenting on the creativity of children aged 5-6 years in Klaten Pedan in the high category. This is shown as many as 27 children obtained a percentage of $89 \%$ had creativity in the high category and 3 children obtained a percentage of $9.9 \%$ in the low category. There are 27 parentsusing democratic parenting, so democratic parenting can said in the high category to support children's creativity. This is shown in the percentage acquisition of democratic parenting category with $89 \%$, while authoritarian parenting obtained a percentage of $6.6 \%$ and permissive parenting obtained a percentage of $3.3 \%$. The results of data analysis in this study, there is a significant relationship between creativity and parenting as indicated by the significance value of 0,000 $<0.05$ with a correlation magnitude of 0.690 . Thus the value of sig $0.123>0.05$, so it can be concluded that there is a linear relationship in parenting parenting towards children's creativity.

\section{REFERENCES}

Diana, W. (2019). Relationship of Parenting Parenting with Preschool Child Fine Motoric Development (at Harapan Bunda PAUD Surabaya). J-Hestech (Journal of Educational Health Science and Technology), 2 (1), 5160.https://ejournal.unitomo.ac.id/index.php /jhest/article/view/1660

Handayani, PH, Gandamana, A., \& Farihah, F. Development of Early Childhood Creativity in Families. Journal of Healthy Welfare Families, $\quad 15 \quad$ (2), 4656.https://jurnal.unimed.ac.id/2012/index.p hp/jkss/article/view/8774

Helmawati.2015. Knowing and Understanding PAUD. Bandung: PT Remaja Rosdakarya

Husna, M., Pransiska, R., \& Yulsyofriend, Y. (2019). The Effect of Washi Origami Paper on Children's Creativity in Aisyiah Kindergarten No. 1 Muara Panas Regency of Solok. POTENSIA Scientific Journal, 4 (1), 67-77. https://doi.org/10.33369/jip.4.1.67-77

Kholifah (2018). The Influence of Parenting Parents Against Emotional Intelligence in Aud Tk Muslimat Nu 1 Tuban. Journal of Children's Education, 7 (1), 61-75. https://doi.org/10.21831/jpa.v7i1.24446

Lestari, M. (2019). Relationship between parenting and children's independence. Journal of Children's Education, 8 (1), 84- 
90.

https://journal.uny.ac.id/index.php/jpa/a rticle/view/26777

Puspita, M., Sutinah, \& Ulfa, M. (2018). Parenting Parenting Creativity with Preschoolers in Al-Azhar Kindergarten, Jambi City. Health Information Research, $7 \quad$ (2), 3-9. http://www.stikeshi.ac.id/jurnal/index.php/rik/article/view $/ 170$

Rahmalina. (2017). Role Playing Method For Early Childhood Creativity 4-6 Years. PAUD Education Journal, 02 (1), 11-23.

Reswita. (2017). Relationship between Parenting Parents with Children's Development Achievement. Journal of Early Childhood Education, 1 (1), 1-11.

Susanto, Ahmad.2017. Early Childhood Education (Concepts and Theories). Jakarta: Earth Literacy 